\title{
Globular Embryo Induction of Sugar Palm (Arenga pinnata (Wurmb) Merr.)
}

\author{
Micha Gracianna Devi, Agus Purwito, and Ali Husni
}

\begin{abstract}
The objective of this study was to get the best media to produce somatic embryos from zygotic embryos of sugar palm. This research was conducted at Tissue Culture Laboratory, Department of Agronomy and Horticulture, Faculty of Agriculture, Bogor Agricultural University from October 2012 to April 2013. This research consisted of three phases which were callus induction, globular embryo induction, and globular embryo maturation. Sterilization using $\mathrm{NaOCl}$ $1.575 \%$ and alcohol $96 \%$ was able to provide the most sterile explants for treatment A1 (MS + $\left.3 \mathrm{mg} \mathrm{l}^{-1} 2,4-\mathrm{D}+2 \mathrm{mg} \mathrm{l}^{-1} \mathrm{NAA}\right)$ of $89 \%(16 / 18)$. During callus induction phase, embryogenic callus were mostly formed at treatment $\mathrm{A5}$ (MS $+3 \mathrm{mg} \mathrm{l}^{-1} \mathbf{2 , 4 -}$ $\mathrm{D}+0.2 \mathrm{mg} \mathrm{l}^{-1} \mathrm{NAA}+100 \mathrm{mg} \mathrm{l}^{-1}$ biotin) which is $73.4 \%$ after 8 weeks. All explants were able to form globular embryos on media B3 (callus A1 to media MS $+4 \mathrm{mg} \mathrm{l}^{-1}$ Kinetin), B6 (callus A1 to media MS $+1 \mathrm{mg} \mathrm{l}^{-1}$ Kinetin $+0.1 \mathrm{mg} \mathrm{l}^{-1}$ TIBA), B12 (callus A2 to media MS $+0.1 \mathrm{mg} \mathrm{l}^{-1}$ Kinetin $+1 \mathrm{mg} \mathrm{l}^{-1}$ TIBA), and B14 (callus A2 to media MS $+1 \mathrm{mg} \mathrm{l}^{-1}$ Kinetin $+1 \mathrm{mg} \mathrm{l}^{-1}$ TIBA) at 2 weeks after treatment (WAT) during embryo globular induction phase. During embryo globular maturation phase, media C11 (globular embryo clumps B9 to media MS + $0.1 \mathrm{mg} \mathrm{l}^{-1} \mathrm{GA}_{3}$ ) was able to induce $70.8 \%$ mature globular embryo clumps.
\end{abstract}

Index Terms-Embryogenesis, globular embryo, plant growth regulators, sugar palm.

\section{INTRODUCTION}

Sugar palm (Arenga pinnata (Wurmb) Merr.) comes from the family Arecaceae which has a high economic value and a good prospect to be developed [1]. All parts of the plant can be utilized and converted into a variety of products such as sugar sap, starch, kolang-kaling (endosperm), or fibers [2]. The usage of this plant is not limited only for consumable products but in terms of conservation it helps to prevent erosion, improve soil macro conditions, improve soil porosity, and trapping rainwater. Another benefit that until now is still being explored is to produce bioethanol as a substitution for fossil fuel.

Sugar palm has not been cultivated in a commercial scale. Most farmers either utilize this plant directly from the forest or those which are grown in their backyard whereas the productivity is relatively low. Providing superior planting material derived from selected high yielding parental trees through plant breeding programs can help increase the productivity of sugar palm. Obstacles which are being faced in order to establish these high yield varieties includes sugar palm's long reproductive cycle, long seed dormancy and

Manuscript received July 12, 2013; revised November 21, 2013.

Micha Gracianna Devi and Agus Purwito are with Department Agronomy and Horticulture, Agriculture Faculty, Bogor Agricultural University, Indonesia (e-mail: michagrcnndv7@gmail.com).

Ali Husni is with Research and Development Center for Biotechnology and Genetic Resources, Indonesia. seed formation, low germination ability, as well as nonuniform seedling growth [2] .

Non-conventional breeding programs through biotechnology is an alternative solution that can help provide high yield varieties. In order to establish these protocols, studies using tissue culture through somatic embryogenesis which is a technique that can be used to grow relatively uniform somatic embryos in a large amount of scale should be initiated. Based on totipotency theory where plant cells can regenerate into a new plantlet, it can open up new opportunities to create varieties with specific characteristics.

According to Nehra and Kartha [3] there are five factors effecting the results when using the tissue culture technique which includes the explants, treatment medias, plant growth regulators, environmental factors, and plant's genotype. This study focuses on the role of plant growth regulator. Auxine induces cell division and cell differentiation. High auxine level will induce root growth, whereas high concentrations of cytokines causes the formation of buds. Giberelin on the other hand effects embryo maturation [4]. The right combination of these hormones can induce embryogenic callus formation which then can be differentiated to become globular embryos. Therefore the purpose of the experiment is to obtain the best media to produce globular embryos of sugar palm which can be useful for future non-conventional breeding.

\section{PROCEDURE}

The experiment was conducted at the Tissue Culture Laboratory 3 Department of Agronomy and Horticulture, Faculty of Agriculture, Bogor Agricultural University from October 2012 to March 2013. The planting materials which are used were sugar palm embryos about 18 months after anthesis from Mount Goong village, Sukanagara district, Cianjur regency, West Java. Materials used to make the basal medias were MS medium (Murashige and Skoog [5]), sugar, activated carbon, VMW (Morel and Wetmore vitamin [6]), casein hydrolysate, glutamine, asparagine, Phytagel, 2,4-D (2,4-dichlorophenoxyasetate) , NAA ( $\alpha$ naftalenasetat acid), kinetin, TIBA (2,3,5-triiodobenzoic acid) and $\mathrm{GA}_{3}$ (giberelic acid 3). Other supporting material which was required were $96 \%$ alcohol, $1.575 \% \mathrm{NaOCl}$, and washing detergent.

The tools used were laminar air flow cabinet (LAFC), autoclave, stereo and light microscope, culture bottles, dissection equipment, analytical balance, magnetic stirrer, $\mathrm{pH}$ paper, oven, and refrigerator. All the explants were place in $25^{\circ} \mathrm{C}-27^{\circ} \mathrm{C}$ termperatured cultureroom whereas during the first phase was positioned in a dark environment and for the second and third phase was in the light condition. The 
statistical analysis tool used was SAS v9 Portable.

The experiment comprises of three stages: 1) callus induction phase, 2) globular embryo induction phase, and 3) globular embryo maturation phase. All the phases were prepared using completely randomized design (CRD) single factor where the composition can be seen in Table I. The first phase consisted of six levels A1 through A6 and six replications consisted of three explant planted in each bottles with a total of 108 units being observed. The second phase consisted of 14 levels B1 to B14 and were replicated three times consisted of one explant per bottle with a total of 42 units of observation. The third phase was consisted of 12 levels $\mathrm{C} 1$ to $\mathrm{C} 12$ and were replicated three times consisted of eight globular embryos each bottle with a total of 288 units of observation. The layout of the experiment was based on the linear formula as follow:

$$
Y_{i k}=\mu+\alpha_{i}+\varepsilon_{i k}
$$

whereas: $i=1,2,3 \ldots ; j=1,2,3 \ldots ; k=1,2,3 \ldots ; Y_{i j k}=$ observation in treatment $i$ and replication-k; $\mu=$ average; $\alpha i=$ the effect of treatment $-i ; \varepsilon i k=$ random effect of treatment-i and replication- $k$.

Quantitative data was analyzed by F-test with 5\% level. If the results showed a significant effect, further tests will be carried out using Duncan's Multiple Range Test at 5\% level.

TABLE I: MEDIA COMPOSITION

\begin{tabular}{|c|c|}
\hline Treatment & Compostition using MS basal media \\
\hline \multicolumn{2}{|c|}{ Callus induction phase } \\
\hline A1 & $3 \mathrm{mg} \mathrm{l}^{-1} 2,4-\mathrm{D}+2 \mathrm{mg} \mathrm{l}^{-1} \mathrm{NAA}$ \\
\hline $\mathrm{A} 2$ & $5 \mathrm{mg} \mathrm{l}^{-1} 2,4-\mathrm{D}+2 \mathrm{mg} \mathrm{l}^{-1} \mathrm{NAA}$ \\
\hline A3 & $2 \mathrm{mg} \mathrm{l}^{-1} 2,4-\mathrm{D}+0.2 \mathrm{mg} \mathrm{l}^{-1} \mathrm{NAA}+100 \mathrm{mg} \mathrm{l}^{-1}$ biotin \\
\hline A4 & $2 \mathrm{mg} \mathrm{l}^{-1} 2,4-\mathrm{D}+0.2 \mathrm{mg} \mathrm{l}^{-1} \mathrm{NAA}+400 \mathrm{mg} \mathrm{l}^{-1}$ biotin \\
\hline A5 & $3 \mathrm{mg} \mathrm{l}^{-1} 2,4-\mathrm{D}+0.2 \mathrm{mg} \mathrm{l}^{-1} \mathrm{NAA}+100 \mathrm{mg} \mathrm{l}^{-1}$ biotin \\
\hline A6 & $3 \mathrm{mg} \mathrm{l}^{-1} 2,4-\mathrm{D}+0.2 \mathrm{mg} \mathrm{l}^{-1} \mathrm{NAA}+400 \mathrm{mg} \mathrm{l}^{-1}$ biotin \\
\hline \multicolumn{2}{|c|}{ Embryo globular induction phase } \\
\hline B1 & Callus from $\mathrm{A} 1$ to media $0.4 \mathrm{mg}^{-1}$ Kinetin \\
\hline B2 & Callus from A1 to media $1 \mathrm{mg}^{-1}$ Kinetin \\
\hline B3 & Callus from A1 to media $4 \mathrm{mg} \mathrm{l}^{-1}$ Kinetin \\
\hline B4 & $\begin{array}{l}\text { Callus from A1 to media } 0.1 \mathrm{mg} \mathrm{l}^{-1} \text { Kinetin }+0.1 \mathrm{mg} \mathrm{l}^{-1} \\
\text { TIBA }\end{array}$ \\
\hline B5 & $\begin{array}{l}\text { Callus from A1 to media } 0.1 \mathrm{mg} \mathrm{l}^{-1} \text { Kinetin }+1 \mathrm{mg} \mathrm{l}^{-1} \\
\text { TIBA }\end{array}$ \\
\hline B6 & Callus from A1 to media $1 \mathrm{mg} \mathrm{l}^{-1}$ Kinetin $+0.1 \mathrm{mg} \mathrm{l}^{-1} \mathrm{TIBA}$ \\
\hline B7 & Callus from A1 to media $1 \mathrm{mg} \mathrm{l}^{-1}$ Kinetin $+1 \mathrm{mg} \mathrm{l}^{-1} \mathrm{TIBA}$ \\
\hline B8 & Callus from A2 to media $0.4 \mathrm{mg} \mathrm{l}^{-1}$ Kinetin \\
\hline B9 & Callus from A2 to media $1 \mathrm{mg} \mathrm{l}^{-1}$ Kinetin, \\
\hline $\mathrm{B} 10$ & Callus from A2 to media $4 \mathrm{mg} \mathrm{l}^{-1}$ Kinetin \\
\hline B11 & $\begin{array}{l}\text { Callus from A2 to media } 0.1 \mathrm{mg} \mathrm{l}^{-1} \text { Kinetin }+0.1 \mathrm{mg} \mathrm{l}^{-1} \\
\text { TIBA }\end{array}$ \\
\hline $\mathrm{B} 12$ & $\begin{array}{l}\text { Callus from A2 to media } 0.1 \mathrm{mg} \mathrm{l}^{-1} \text { Kinetin }+1 \mathrm{mg} \mathrm{l}^{-1} \\
\text { TIBA, }\end{array}$ \\
\hline B13 & Callus from A2 to media $1 \mathrm{mg} \mathrm{l}^{-1}$ Kinetin $+0.1 \mathrm{mg} \mathrm{l}^{-1} \mathrm{TIBA}$ \\
\hline $\mathrm{B} 14$ & Callus from A2 to media $1 \mathrm{mg}^{-1}$ Kinetin $+1 \mathrm{mg} . \mathrm{l}^{-1}$ TIBA \\
\hline \multicolumn{2}{|c|}{ Globular embryo maturation phase } \\
\hline $\mathrm{C} 1$ & Globular embryo clumps from $\mathrm{B} 2$ to media $0.1 \mathrm{mg} \mathrm{l}^{-1} \mathrm{GA}_{3}$ \\
\hline $\mathrm{C} 2$ & Globular embryo clumps from $\mathrm{B} 3$ to media $0 \mathrm{mg} \mathrm{l}^{-1} \mathrm{GA}_{3}$ \\
\hline $\mathrm{C} 3$ & Globular embryo clumps from B4 to media $0.1 \mathrm{mg} \mathrm{l}^{-1} \mathrm{GA}_{3}$ \\
\hline $\mathrm{C} 4$ & Globular embryo clumps from $\mathrm{B} 5$ to media $0 \mathrm{mg} \mathrm{l}^{-1} \mathrm{GA}_{3}$ \\
\hline $\mathrm{C} 5$ & Globular embryo clumps from $\mathrm{B} 6$ to media $0.1 \mathrm{mg} \mathrm{l}^{-1} \mathrm{GA}_{3}$ \\
\hline C6 & Globular embryo clumps from $\mathrm{B} 7$ to media $0 \mathrm{mg} \mathrm{l}^{-1} \mathrm{GA}_{3}$ \\
\hline $\mathrm{C} 7$ & Globular embryo clumps from $\mathrm{B} 9$ to media $0 \mathrm{mg} \mathrm{l}^{-1} \mathrm{GA}_{3}$ \\
\hline $\mathrm{C} 8$ & $\begin{array}{l}\text { Globular embryo clumps from B10 to media } 0.1 \mathrm{mg} \mathrm{l}^{-1} \\
\mathrm{GA}_{3} \text {, }\end{array}$ \\
\hline C9 & $\begin{array}{l}\text { Globular embryo clumps from B11 to media } 0.1 \mathrm{mg} \mathrm{l}^{-1} \\
\mathrm{GA}_{3}\end{array}$ \\
\hline $\mathrm{C} 10$ & Globular embryo clumps from B12 to media $0 \mathrm{mg} \mathrm{l}^{-1} \mathrm{GA}_{3}$ \\
\hline $\mathrm{C} 11$ & $\begin{array}{l}\text { Globular embryo clumps from B13 to media } 0.1 \mathrm{mg} \mathrm{l}^{-1} \\
\mathrm{GA}_{3}\end{array}$ \\
\hline $\mathrm{C} 12$ & Globular embryo clumps from B14 to media $0 \mathrm{mg} \mathrm{l}^{-1} \mathrm{GA}_{3}$ \\
\hline
\end{tabular}

The experiment began with the preparation of explants which were sugar palm fruits about 18 months after anthesis. These fruits were soaked in detergent for approximately 15 minutes and rinsed off with clean water. Endosperms containing embryo were isolated, soaked in $1.575 \% \mathrm{NaOCl}$ solution for 5-10 minutes and rinsed with distilled water. They were then soaked in $96 \%$ alcohol for 10-15 minutes and placed in the LAFC.

Preparing the treatment media started out by inserting 20 $\mathrm{ml}$ of media solution into sterile bottles, autoclaving them for 15 minutes at $121^{\circ} \mathrm{C}$ under $1.5 \mathrm{~kg} \mathrm{~cm}^{-3}$ and keeping them inside cultured room. The planting process was done in the LAFC. Embryos were isolated one at a time by burning the endosperm on the bunsen burner and collecting them inside a petri dish. The embryos $(0.1-0.5 \mathrm{~cm})$ collected then were transferred to treatment media.

\section{RESULTS}

\section{A. General Condition}

Sugar palm (Arenga pinnata (Wurmb) Merr.) is an Angiosperm that comes under the Arecaceae family [2]. The fruits consists of the exocarp, mesocarp, seed coat, endosperm and the embryo. Endosperm stores nutrition for the embryo and when it is ripe, it will harden making it insoluble and hard to break [7]. Therefore in this experiment, only explants with endosperm that are still at gel like stage were isolated.

This experiment began with the preparation of sugar palm fruit which were taken from the first female bunches of a matured tree. The fruits were then kept one week in a sack for forced-ripening the followed by the zygotic embryo isolation process which should be done carefully to avoid damages.

During the callus induction phase (1-8 WAT), contaminated cultures were mainly caused by fungi and bacteria. Suspected that the source of contamination were caused either during zygotic embryos isolation, planting process, or the environment of culture room which wasn't too sterile.

The role of auxine and dark condition is crucial to induce callus formation. The presence of light inhibits germination and would stimulate photosynthesis making it difficult to direct the explant for inducing calluses [8]. In most treatments, calluses started to appear at 4-8 WAT. Compact calluses were mainly formed appearing on the surface of explants. In some cases, white flosses appeared and develop covering up potential embryogenic calluses.

During globular embryo induction phase, calluses were transferred to different treatment medias under light condition which caused an increase in size, a change in color (more green) and form globular somatic embryos. The immature globular embryo clumps when they're too quickly transferred into the globular embryo maturation media could result in cell death, whereas if they were transferred later than they should have would fail to developed into matured embryos. Some explants formed pseudo-roots (pneumathode) which inhibits the formation of globular embryos. 
During the globular embryo maturation phase, several explants failed to develop due to the separation process of the clumps. Dead globular embryo clumps appear black in color and found brownish fluid around them (phenolic substance). Matured globular embryo tend to have a shiny yellowish white surface color different when seen on the haustoria's surface of newly planted embryos. After 2 WAT, germinated somatic embryos still weren't obtained. Different stages of the explant found in this experiment can be seen in Fig. 1.

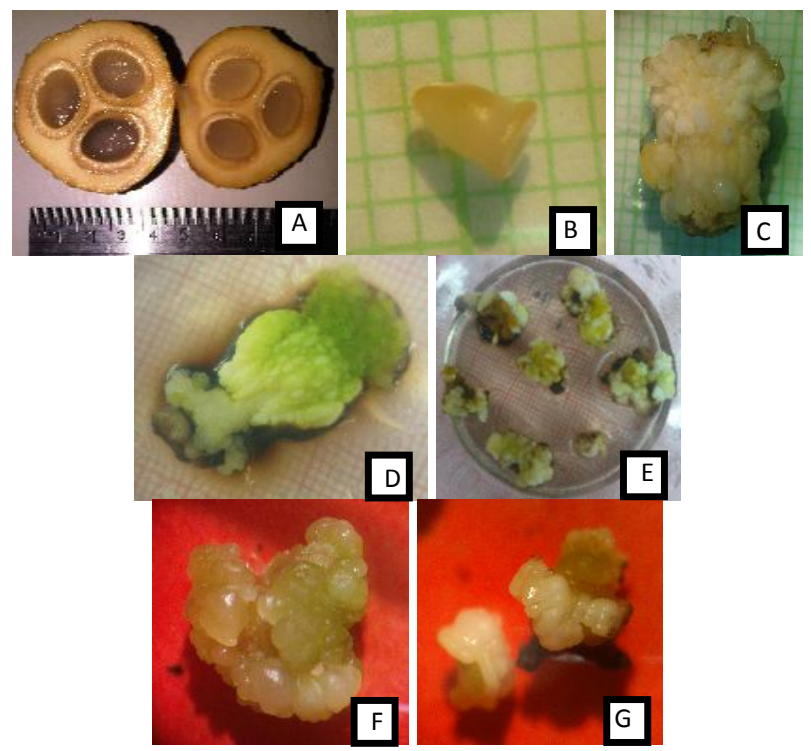

Fig. 1. Sugar palm explant development. A) Fruit aged \pm 18 months from Mount Goong village, West Java. B) Embryo that have been isolated from the endosperm. C) Embryogenic callus on the surface explant during callus induction phase. D) Explant appearance during the globular embryo induction phase. E) Globular embryo clumps during globular embryo maturation phase. F) Immatured globular embryo. G) Matured globular embryo clumps.

\section{Phase 1: Callus Induction}

\section{1) The percentage and total of sterile explants}

Sterile explant is a major requirement in performing a successful tissue culture procedure. The reponse of cultured explants in different treatments can be seen in Fig. 2. The highest amount of sterile explants was in treatment A1at $89 \%$ (16/18). Sterile explants on media A2, A3, A4, A5, and A6 respectively 50\% (9/18), 16.7\% (15/18), 22.2\% (14/18), $16.7 \%(15 / 18)$, and $16.7 \%(15 / 18)$. Various percentage of sterile culture result may be related to treatment during the culture process.

The sources of contamination were fungi and bacteria. Contaminated cultures caused by fungi were characterized by the hyphaes and spores whereas for bacteria were characterized by milky white mucus seen in Fig. 3 [9]. The appearance of these contamination sources could be caused by the sterilization process that wasn't conducted well, uncarefulness when moving explants to treatment media, unsterile culture environment, unsterilized tools, and explants which contained systemic bacterias [10]. According to Thaib [11] soaking the endosperm with $70 \%$ alcohol for a few seconds, followed by $0.05 \% \mathrm{HgCl}_{2}$ solution for 25 minutes was effective in sterilizing shoot tip and root tip or sugar palm. In this experiment, sterilization using $\mathrm{HgCl}_{2}$ solution was not performed because of the toxicity of this substance. Sterilization using alcohol $96 \%$ and $1.575 \% \mathrm{NaOCl}$ managed to provide high percentage of sterile embryo explants.

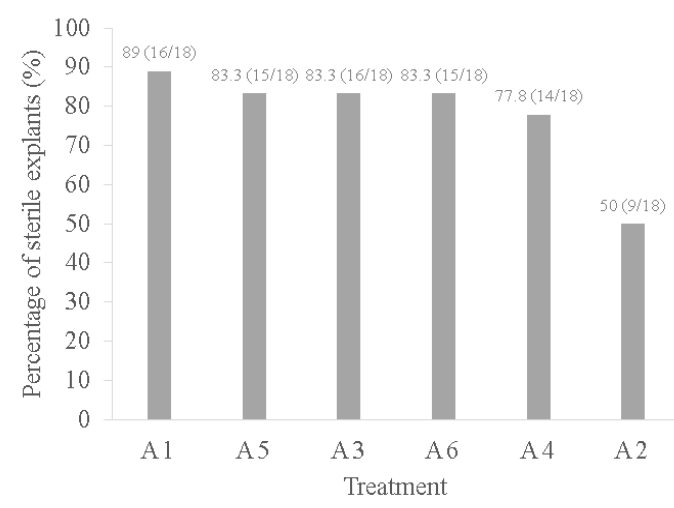

Fig. 2. The percentage and total sterile explants at 8 WAT. Avalues inside parentheses indicate the number of embryogenic calluses.

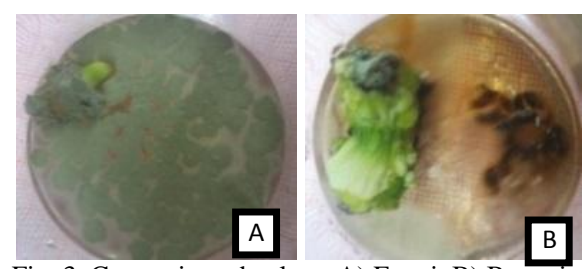

Fig. 3. Contaminated culture A) Fungi. B) Bacteria

\section{2) The percentage and total explants that formed callus}

Callus formation response on explants which were cultured in treatment media containing auxine is a factor that was observed in this experiment. The results in Fig. 6 showed that the highest percentage of explants that to form calluses at 4 WAT were in treatment $\mathrm{A} 1$ and $\mathrm{A} 6$ at $77.8 \%$ (14/18). In treatment A2, A3, A4 and A5 the percentage were respectively $38.8 \%$ (7/18), $53.4 \%$ (8/18), $73.4 \%$ $(11 / 15)$, and $50.2 \%(9 / 15)$. Calluses on each explants were formed at different times but the results showed an increase in numbers from 4-8 WAT. At 8 WAT, treatment A4 was able to form the most callus at $100 \%(12 / 12)$ of the total explants where as treatment A3 was able to form the least callus at $80.2 \%(12 / 15)$ of the total explants. The addition of vitamin biotin provided in the treatment medias that already contained $2 \mathrm{mg} \mathrm{l}^{-1} 2,4-\mathrm{D}$ and $0.2 \mathrm{mg} \mathrm{l}^{-1} \mathrm{NAA}$ may help promote callus formation. Biotin is believed to act as a coenzyme that could boost protein synthesis.

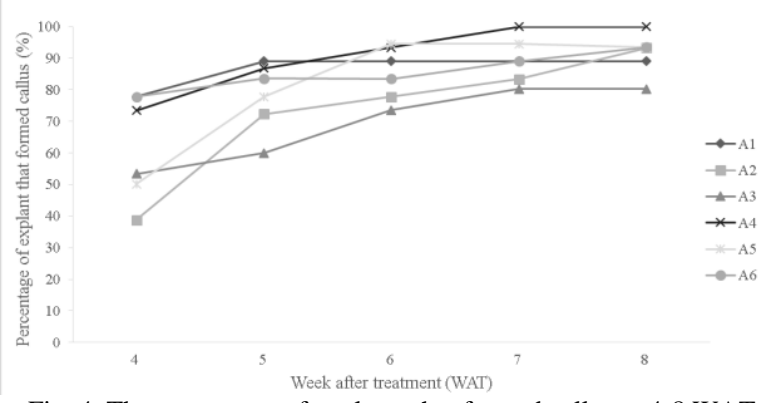

Fig. 4. The percentage of explants that formed callus at 4-8 WAT.

Callus growth responses of zygotic embryo explants used were seen at 4 WAT. According to Asikin and 
Puspitaningtyas [8], faster response were seen when using embryo without endosperm as an explant because water and the nutrients would be more easier absorbed with the direct contact between the embryos and the plant growth regulators embedded in the media.

\section{3) The percentage and total explants that formed embryogenic callus and average percentage of callus coverage on explant}

Somatic embriogensis is a process by which somatic cells can be directed to form new plants through specific embryonic development stages without going through gamete fusion [12]. In order to produce somatic embryo, callus must be induced. These calluses have the potential to become embryogenic calluses. Reference used to determine the percentage of callus coverage on explants could be seen in Fig. 5. In Table II, treatment A1 at $72.2 \%$ was able to induce the most callus coverage on the surface of the explants but not significantly different from A2, A3, A4, and A6. Plant growth regulator 2,4-D which was added to the media is a type of synthetic auxine that stimulates cell division and cell growth [4]. The addition of 2,4-D in the culture medium was needed to induce nodular embryogenic structure during the somatic embryogenesis induction phase of Bactris gasipaes [13].

Treatment A5 at 51.3\% showed the least percentage of callus coverage. However, when compared to A1, the addition of $100 \mathrm{mg} \mathrm{l}^{-1}$ biotin tends to be less supportive to induce more callus formation. Thus, the addition of biotin or vitamin $\mathrm{H}$ which is a key carboxylation allegedly should have the capability to stimulate faster synthesis of fats just like in the experiment that has been conducted by El-shiaty et al. [14] which showed $93.7 \%$ of the total formation of callus obtained from MS medium $+5 \mathrm{mg} \mathrm{l}^{-1}$ biotin in date palms.

The addition of $400 \mathrm{mg} \mathrm{l}^{-1}$ biotin was able to increase the percentage of callus coverage for treatment A4 and A6 when compared to the addition of $100 \mathrm{mg} \mathrm{l}^{-1}$ biotin in treatment A3 and A5. However based on the statistical test, the results were not significantly different thefore biotin which were usually added about $0.01-1.0 \mathrm{mg} \mathrm{l}^{-1}$ stated by Bhojwani and Razdan (1983) [15] actually can be added up to more than $1 \mathrm{mg} \mathrm{l}^{-1}$ for sugar palm culture.

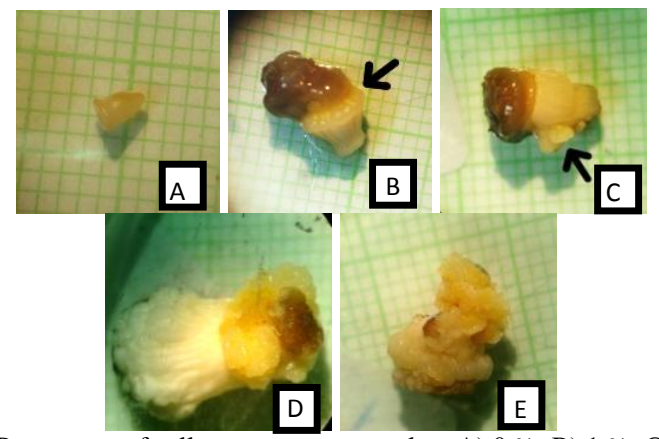

Fig. 5. Percentage of callus coverage on explant A) $0 \%$; B) $1 \%$; C) $10 \%$; D) $50 \%$; E) $100 \%$

Embryogenic callus is a condition where calluses were able to regenerate into a plantlet through somatic embryogenesis or organogenesis. Generally, all the treatment medias which were used could produce embryogenic calluses. The result shown in Table II stated that the percentage of embryogenic callus that appeared the most was in treatment A5 at $73.4 \%$ (11/15) although not significantly different from other treatments. While treatment A6 at $49.9 \%$ (9/18) was producing the least embryogenic callus

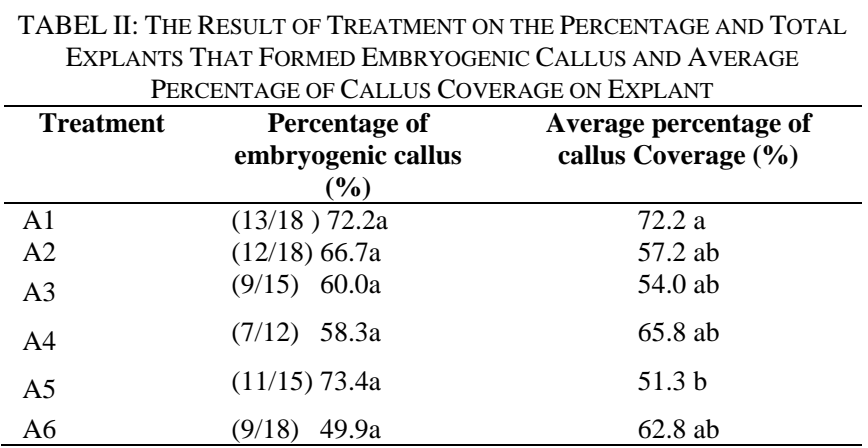

${ }^{\mathrm{a}}$ The numbers followed by the same letter in the same column indicates no significant difference based on DMRT at $\alpha=5 \%$; values inside parentheses indicate the number of embryogenic calluses.

The embryogenic cells seen in Fig. 6 A) is characterized by a smooth surface, as well as composed of cells that divide parallel and perpendicular to the surface of the callus [16]. Embryogenic cells tend to have a shiny surface and are not transparent. Non-embryogenic callus are shown in Fig. 6 B) and Fig. 6 C). Fig. 6 showed the structure of the white floss on the surface of the callus. The embryogenic callus will be covered and failed to develop if no further treatment were taken. Formation of white flosses may be associated with the auxine and cytokines balance. Explants with white flosses reduces the amount of embryogenic callus formed therefore there will be less explants which can be used for globular embryo induction treatments.
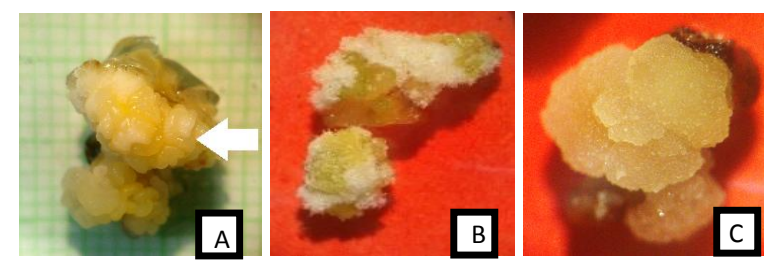

Fig. 6. Types of callus A) embryogenic (A2); B) non-embryogenic with white floss (A6); C) non-embryogenic withoug white floss (A3).

\section{Phase 2: Embrio Globular Induction}

\section{1) The percentage and total explants that formed} globular embryos

Somatic embryogenesis in palm trees generally consists of several stages which include globular, scutelar, and cotyledonary stage. The results in Fig. 7 shows treatment B3, B6, B12, and B14 were all able to form globular embryos at 2 WAT. In treatment B1, B2, B8, B10, B11, and B13 only $66.7 \%(2 / 3)$ of the total planted explants were able to form globular embryos. While on treatment B4, B5, B7, and B9 only $33.3 \%(1 / 3)$ of the total planted explants were able to form globular embryos. The successful rate to form globular embryos in this experiment is still low considering the explants used comes from zygotic embryos with diverse genotypes meaning the stimulation of each individuals differ from one another [4]. The formation of globular somatic embryos which took 9-10 weeks after initial 
planting were slower when compared to oil palm which took only 4-6 weeks after initial planting [16].

At the globular embryo induction phase, plant growth regulators cytokines and antiauxine were expected to induce globular embryo formation. According to Chawla (2002), cytokine is the derivative of adenine and have an important role in the induction of buds, plant growth and development as well as cell division when combined with auxine.

Callus obtained from treatment media with $3 \mathrm{mg} \mathrm{l}^{-1}$ 2,4-D and $2 \mathrm{mg} \mathrm{l}^{-1} \mathrm{NAA}$ then transferred to treatment media $4 \mathrm{mg}$ $1^{-1}$ Kinetin was able to form more globular embryos compared to when place in treatment media with 0.4 and 1 $\mathrm{mg} \mathrm{l}^{-1}$ Kinetin. The use of lower auxine concentration in the previous stage and then high concentration cytokine gives the best results, although the genetic stability is still unsure due to the occurrence of somaclonal variation. Whereas treatment with callus obtained from media with $5 \mathrm{mg} \mathrm{l}^{-1} 2,4$ $\mathrm{D}$ and $2 \mathrm{mg} \mathrm{l}^{-1}$ NAA were then transferred to media who were given $1 \mathrm{mg} \mathrm{l}^{-1}$ Kinetin apparently produced the least globular embryos. It is predicted that the concentration of cytokines given were still lower than the endogenic as well as the additional auxine given at the previous phase.

The use of Kinetin and TIBA at various concentration gives different results for calluses obtained from treatment media with $2 \mathrm{mg} \mathrm{l}^{-1} \mathrm{NAA}$ and placed in treatment media with 3 or $5 \mathrm{mg} \mathrm{l}^{-1} 2,4-\mathrm{D}$. The callus obtained from $2 \mathrm{mg} \mathrm{l}^{-1}$ NAA and $3 \mathrm{mg} \mathrm{l}^{-1}$ 2,4-D on the other hand showed the the highest amount of globular embryos when placed in treatment media with $1 \mathrm{mg} \mathrm{l}^{-1}$ Kinetin and $0.1 \mathrm{mg} \mathrm{l}^{-1}$ TIBA. While the calluses which were obtained from $2 \mathrm{mg} \mathrm{l}^{-1}$ NAA and $5 \mathrm{mg} \mathrm{l}^{-1} 2,4-\mathrm{D}$ then were placed in treatment media with $0.1 \mathrm{mg} \mathrm{l}^{-1}$ Kinetin and $1 \mathrm{mg} \mathrm{l}^{-1}$ TIBA as well as $1 \mathrm{mg}$ TIBA $1^{-1}$ Kinetin and $1 \mathrm{mg} \mathrm{l}^{-1}$ TIBA were able to produce the most callus with globular embryos. Sugar palm is predicted to have a high concentration of endogenous auxin therefore no exogenous auxin is added at the globular embryo induction phase. Instead, TIBA which is an antiauxin that helps suppress levels of endogenous auxin was added in exchange [18].

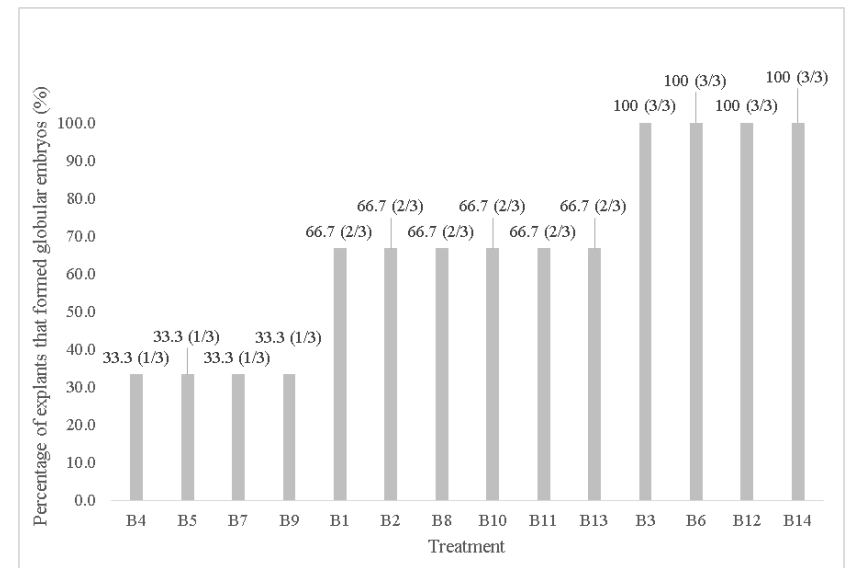

Fig. 7. The percentage of explants that formed globular embryos at 2 WAT. ${ }^{a}$ Values inside parentheses indicate the number of embryogenic calluses.

\section{2) The average number of pseudoroots}

The balance between plant growth hormone auxine and cytokine could be manipulated to form somatic embryos and organogenesis. Embryogenic calluses which were treated were expected to develop into somatic embryos which then germinate and produce sprouts. However, sometimes the hormonal balance tends to go towards root formation. Fig. 8 shows treatment B7 was able to form the highest amount of pseudoroots which were approximately six roots per explants but was not significantly different when compare to treatment B1 with an average of four pseudo roots per explants. Treatment B2, B3, B9, and B12 were not able to form psudoroots therefore they appear to be the best medium to direct embryogenic calluses to form globular embryos which has the potential to germinate and produces sprouts.

Fig. 9 shows the appearance of pseudoroots caused by the higher amount of auxine concentration than cytokine therefore cells were more likely to differentiate towards root formation rather than bud formation (Asikin and Puspitaningtyas 2000). When callus roots were formed before the shoot, it will be harder to differentiate the embryos towards shoot formation. In this experiment, a number of pseudoroots were formed without the addition of exogenous auxine which proved that endogenous auxine in the explants was high despite the addition of cytokines and antiauxines.

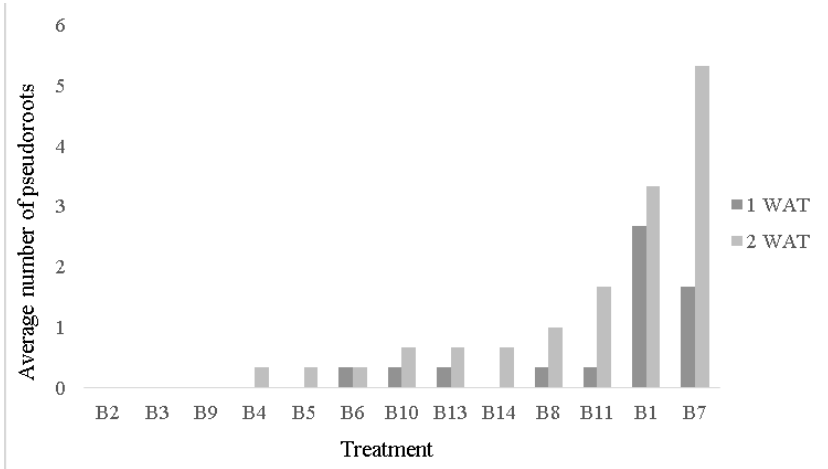

Fig. 8. Average number of pseudoroots at 1-2 WAT.

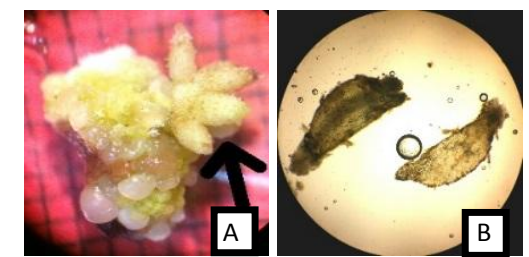

Fig. 9. Sugar palm pseudoroot A) Pseudoroot on callus surface (B11). B) Transversal cut of pseudoroot.

\section{Phase 3: Embryo Globular Maturation}

The Percentage and Total Matured and Alived Globular Embryo Clumps

The globular phase of a somatic embryo is the earliest stage before it develops into plantlets through somatic embryogenesis process. Collection of globular embryos obtained from previous phase were separated using a scalpel and planted onto the new treatment medias. Table III shows treatment $\mathrm{C} 8$ were able to maintain all lived globular embryo clumps up to 2 WAT but it wasn't significantly different compared to treatment $\mathrm{C} 1, \mathrm{C} 2, \mathrm{C} 3, \mathrm{C} 4, \mathrm{C} 6, \mathrm{C} 7$, $\mathrm{C} 10, \mathrm{C} 11$, and $\mathrm{C} 12$. Treatment $\mathrm{C} 9$ caused death in all the explants. Globular embryos that failed to develop turned brown and secreted brown liquid substances around it as 
shown in Fig. 10 Similar appearance could be found after separating protocorm protocorm like bodies (PLB) of Phalaenopsis amabilis. The browning symptoms were due to the accumulation of oxidized phenol caused but cell injury as a result of the separation [10]. Immature globular embryos before being planted in the new treatment can be seen in Fig. 10.

TABLE III: The Result of TREATMENT ON THE PERCENTAGE AND TOTAL MATURED AND ALIVED GLOBULAR EMBRYO CLUMPS

\begin{tabular}{|c|c|c|c|c|c|c|}
\hline \multirow{3}{*}{$\begin{array}{l}\text { Treatment } \\
\text { C1 }\end{array}$} & \multicolumn{4}{|c|}{ Percentage of alived globular embryo clumps (\%) } & \multirow{2}{*}{\multicolumn{2}{|c|}{$\begin{array}{l}\text { Percentage of matured } \\
\text { embryo clumps }(\%)\end{array}$}} \\
\hline & \multicolumn{2}{|l|}{1 MSP } & \multicolumn{2}{|l|}{2 MSP } & & \\
\hline & $(19 / 24)$ & $79.2 \mathrm{a}$ & $(18 / 24)$ & $75.0 \mathrm{ab}$ & $(9 / 24)$ & $37.5 \mathrm{abc}$ \\
\hline $\mathrm{C} 2$ & $(23 / 24)$ & $95.8 \mathrm{a}$ & $(22 / 24)$ & $91.7 \mathrm{a}$ & $(7 / 24)$ & $29.2 \mathrm{bc}$ \\
\hline $\mathrm{C} 3$ & $(24 / 24)$ & $100.0 \mathrm{a}$ & $(21 / 24)$ & $87.5 \mathrm{ab}$ & $(13 / 24)$ & $54.2 \mathrm{ab}$ \\
\hline $\mathrm{C} 4$ & $(22 / 24)$ & $91.7 \mathrm{a}$ & $(20 / 24)$ & $83.3 \mathrm{ab}$ & $(10 / 24)$ & $41.7 \mathrm{ab}$ \\
\hline $\mathrm{C} 5$ & $(17 / 24)$ & $70.8 \mathrm{a}$ & $(13 / 24)$ & $54.2 \mathrm{~b}$ & $(8 / 24)$ & $33.3 \mathrm{abc}$ \\
\hline C6 & $(20 / 24)$ & $83.3 \mathrm{a}$ & $(20 / 24)$ & $83.3 \mathrm{ab}$ & $(13 / 24)$ & $54.2 \mathrm{ab}$ \\
\hline $\mathrm{C} 7$ & $(18 / 24)$ & $75.0 \mathrm{a}$ & $(18 / 24)$ & $75.0 \mathrm{ab}$ & $(7 / 24)$ & $29.2 \mathrm{bc}$ \\
\hline $\mathrm{C} 8$ & $(24 / 24)$ & $100.0 \mathrm{a}$ & $(24 / 24)$ & $100.0 \mathrm{a}$ & $(6 / 24)$ & $25.0 \mathrm{bc}$ \\
\hline $\mathrm{C} 9$ & $(0 / 24)$ & $0.0 \mathrm{~b}$ & $(0 / 24)$ & $0.0 \mathrm{c}$ & $(0 / 24)$ & $0.0 \mathrm{c}$ \\
\hline $\mathrm{C} 10$ & $(23 / 24)$ & $95.8 \mathrm{a}$ & $(22 / 24)$ & $91.7 \mathrm{a}$ & $(8 / 24)$ & $33.3 \mathrm{abc}$ \\
\hline $\mathrm{C} 12$ & $(23 / 24)$ & $95.8 \mathrm{a}$ & $(23 / 24)$ & $95.8 \mathrm{a}$ & $(11 / 24)$ & $45.8 \mathrm{ab}$ \\
\hline
\end{tabular}

${ }^{\mathrm{a}}$ The numbers followed by the same letter in the same column indicates no significant difference based on DMRT at $\alpha=5 \%$.
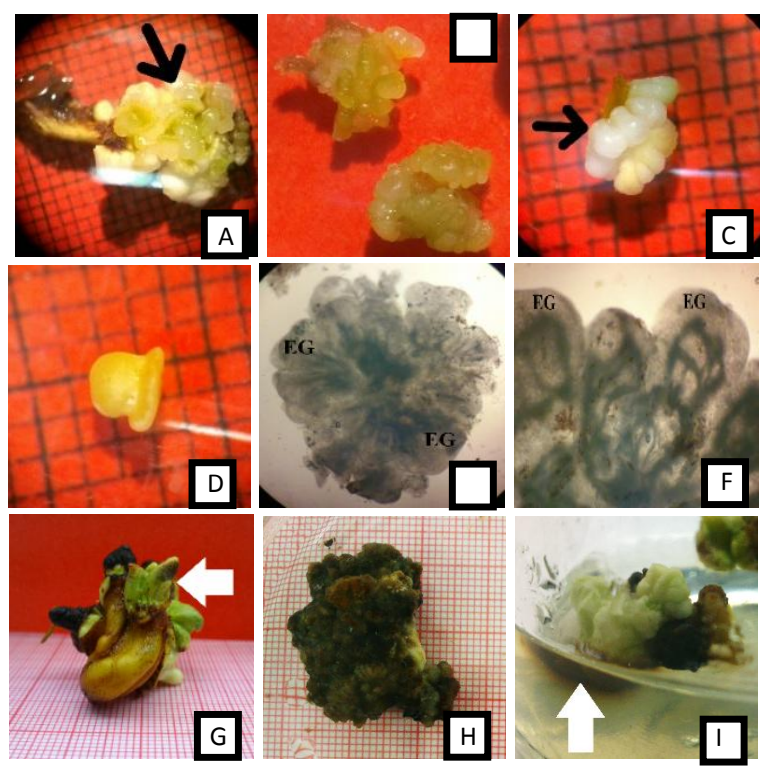

Fig. 10. Globular embryo immatured and matured A) Immatured globular embryo clump attached on haustoria (C11). B) Immatured globular embryo clump separated (C6). C) Matured globular embryo clump (C11). D) Individual globular embryo (C11). E) Transversal insicion of globular embryo clump (C6). F) Transversal cut of globular embryos. G) Potential bud on explant surface. H) Dead callus. I) Phenol secretion on the surface of matured globular embryo clump. EG: globular embryo. A and C using 100x magnification. $\mathrm{B}$ and D using $200 \mathrm{x}$ magnifications. E and $\mathrm{F}$ using $400 \mathrm{x}$ magnifications.

Providing nutrition, hormones and time were some requirements to develop the globular embryos into the scutelar phase. Statistical test results showed that the percentage of matured globular embryo clumps were mostly found in treatment $\mathrm{C} 11$ at $70.8 \% \quad(22 / 24)$ but not significantly different from $\mathrm{C} 1, \mathrm{C} 3, \mathrm{C} 4, \mathrm{C} 5, \mathrm{C} 6, \mathrm{C} 10$, and C12. The characteristics of matured globular embryo clumps were milky white or yellowish color with a shiny surface as seen in Fig. 10 C) and Fig. 10 D). Fig. 10 E) and Fig. $10 \mathrm{~F}$ ) shows the microscopic appearance of the transversal incision of the explants. Treatment C9 did not produce matured globular embryo clumps because all the explants died.

The addition of $0.1 \mathrm{mg} \mathrm{l}^{-1} \mathrm{GA}_{3}$ on treatment didn't have a significant impact to the result because the influence of plant growth regulators on the previous treatments were still contributing to the development of matured globflar embryos. Another reason why that this set of treatment didn't have a significant impact to the result was because the short amount of observation time. Results were only observed until 2 WAT during this phase due to the large amount of contamination caused by fungi. However, a preshoot structure was suspected found in explants that were not contaminated seen in Fig. 10.

\section{CONCLUSION}

Sterilization using $\mathrm{NaOCl} 1.575 \%$ and $96 \%$ alcohol resulted 50-85\% sterile explants. Embryogenic callus were induce the higherst amount at treatment A5 (MS + $3 \mathrm{mg} \mathrm{l}^{-1}$ $2,4-\mathrm{D}+0.2 \mathrm{mg} \mathrm{l}^{-1} \mathrm{NAA}+100 \mathrm{mg} \mathrm{l}^{-1}$ biotin) at $73.4 \%$ $(11 / 15)$ during callus induction phase. Treatment B3 (callus from A1 to $4 \mathrm{mg} \mathrm{l}^{-1}$ Kinetin), B6 (callus from A1 to $1 \mathrm{mg} \mathrm{l}^{-1}$ Kinetin $+0.1 \mathrm{mg} \mathrm{l}^{-1}$ TIBA), B12 (callus from A2 to $0.1 \mathrm{mg}$ $\mathrm{l}^{-1}$ Kinetin $+1 \mathrm{mg} \mathrm{l}^{-1}$ TIBA), and B14 (callus from A2 to 1 $\mathrm{mg} \mathrm{l}^{-1}$ Kinetin $+1 \mathrm{mg} \mathrm{l}^{-1}$ TIBA) were able to form globular embryos for all explants that were planted during the globular embryo induction phase. At the globular embryo maturation stage, treatment C11 (globular embryo clumps from $\mathrm{B} 9$ to $0.1 \mathrm{mg} \mathrm{l}^{-1} \mathrm{GA} 3$ ) was able to produce the highest amount of matured embryo globular clumps at $70.8 \%$ (22/24).

\section{REFERENCES}

[1] R. Putih, B. Satria, and R. Thaib. "Upaya perbanyakan vegetatif enau (Arenga pinnata (Wurmb) Merr.) melalui regenerasi tunas secara in vitro," Stigma, 2003, vol. 11, no. 3, pp. 208-212.

[2] S. Soeseno, Bertanam Aren, Jakarta (ID): Penebar Swadaya, 2000. 
[3] N. S. Nehra and K. K. Kartha, "Meristem and shoot tip culture," in I. K. Vasil, T. A. Thorpe, Plant Cell and Tissue Culture, Dordrecht, NL: Kluwer Academic Publishers, 1990, pp. 37-70.

[4] A. Slater, N. Scott, and M. Fowler, Plant Biotechnology: The Genetic Manipulation of Plants, 2nd Edition, London, UK: Oxford University Press, 2008.

[5] T. Murashige and F. Skoog, "A revised medium for rapid growth and bioassays with tobacco tissue cultures," in F. Muniran, S. J. Bhore, F. H. Shah, Microprogation of Elaeis guineensis Jacq. Dura: Comparison of three basal media for efficient regeneration, 2008, Indian J. Exp. Biol, 1962, vol. 46, pp. 79-82.

[6] G. Morel, "Sur la culture des tissus de deux monocotyledones," in B. Panis and N. T. Thinh, Cryopreservation of Musa Germplasm, 1950, pp. 33, 2013

[7] Z. Untu, D. B. Taulu, J. Kumaunang, and R. H. Akuba, "Pertumbuhan dan perkembangan embrio tanaman aren," Laporan Tahunan Balitka 1996/1997, Manado, ID: Balitka, 1998, pp. 308-317.

[8] D. Asikin and D. M. Puspitaningtyas, "Studi perkecambahan biji aren (Arenga pinnata (Wurmb.) Merr.) secara in vitro dan in vivo," in M A. Subroto, Prosiding Seminar Hasil Penelitian dan Pengembangan Bioteknologi III, Seminar Hasil Penelitian dan Pengembangan Bioteknologi III, March 7-9, 2000, pp. 411-419.

[9] A. S. Yudhanto, "Pengaruh kombinasi NAA dengan sitokinin (BAP, Kinetin, 2iP) terhadap daya proliferasi tanaman kantong semar (Nepenthes mirabilis) secara invitro," thesis, Bogor, ID: Institut Pertanian Bogor, 2012.

[10] E. Raynalta, "Pengaruh komposisi media dalam pertumbuhan PLB, plantlet, dan aklimatisasi Phalaenopsis amabilis," thesis, Bogor, ID: Insititut Pertanian Bogor, 2013.

[11] R. Thaib, "Mendapatkan cara sterilisasi eksplan enau (Arenga pinnata Merr.) yang tepat dan efektif," Universitas Andalas, 2008.

[12] H. S. Chawla, Introduction to Plant Biotechnology, 2nd Edition, Enfield, USA: Science Publishers, 2002.

[13] A. D. Maciel, P. C. P. F. Fermino, R. A. D. Silva, and J. E. S. Pereira, "Morpho-anatomical characterization of embryogenic calluses from immature zygotic embryo of peach palm during somatic embryogenesis," Acta Scientiarum: Agronomy, 2010, vol. 32, no. 2, pp. 263-267.

[14] O. H. EL-Shiaty, S. F. El-Sharabasy, and A. H. A. El-Kareim, "Effect of some amino acids and biotin on callus and proliferation of date palm (Phoenix dactylifera L.) Sewy cultivar," 2004.

[15] S. S. Bhojwan and M. K. Razdan, Plant tissue culture: theory and practice, Amsterdam, NE: Elsevier, 1983.

[16] O. Rohani, S. A. Sharifa, M. Y. Rafii, M. Ong, A. H. Tarmizi, and I. Zamzuri, "Tissue culture of Oil palm," in T. Basiron, B. S. Jalani, and K.W. Chan, Advances in Oil Palm Research I, Kuala Lumpur, MY Malaysian Palm Oil Board, pp 19-38.

[17] A. Husni, M. Kosmiatin, and A. Purwito, "Embriogenesis somatik langsung pada tanaman kelapa sawit," in A. Suryani, K. Syamsu, D. Saputra, K. S. Suparman, I. Sulaeman, and Y. Sukmawati, Prosiding Akselerasi lnovasi Industri Kelapa Sawit untuk Meningkatlam Daya Saing Global, Seminar Nasional dan Kongres MAKSI, January 26, 2012, pp. 412-418
[18] A. Dovzhenko, "Towards plastid transformation in rapeseed (Brassica napus L.) and sugarbeet (Beta vulgaris L.)," disertation, Munich, DE: Universität München, 2001.

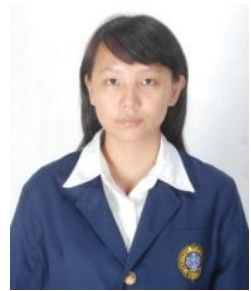

Micha Gracianna Devi was born in Bogor on July 2nd, 1991 and was raised by her father Leonard J. Lammerink and her mother Fujiyati Lammerink and have a younger sister. In 2009 the author graduated from SMA Negeri 3 Bogor senior high school and in the same year the author was invited to become a student in Department of Agronomy and Horticulture, Faculty of Agriculture, Bogor Agricultural University (IPB).

During her studies, she became a laboratory assistant on plant breeding (undergraduate-2012/2013), ornamental plants (undergraduate-2012/2013), and horticultural crops (diploma-2012/2013).

The author also participated in the student exchange program (credit earning) MIT to Kasetsart University in Thailand for one semester in 2011 , an exchange student to the University of Santiago de Compostela in Spain through the Experts II program, Erasmus Mundus (2013-2014) for a semester, and to the Blekinge Institute of Technology in Sweden for one week to attend the World Student Environmental Summit with the financial support from Indonesian Ministry of Higher Education and Bayer Indonesia. The author also has been active as a member in the International Association of Students in Agriculture and Related Sciences IPB, and IPB Debate Club.

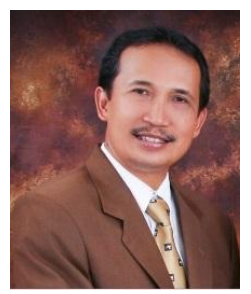

Agus Purwito was born in Jember on November 1st $\mathrm{He}$ got his $\mathrm{PhD}$ degree in Plant Biotechnology, Bogor Agricultural University in 1994. He's currently working as the head of department of Agronomy and Horticulture, Bogor Agricultura University and got a predicate as the first ranked national head of department in Indonesia 2013. His last research was Two different bacillus thuringiensis toxin genes confer resistance to beet armyworm (Spododopteraexigua) in transgenic Bt- shallot (Allium cepa L.).

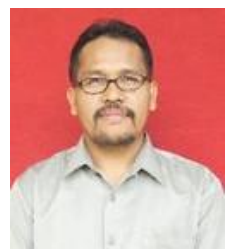

Ali Husni was born in Padang Sidempuan on December 9th, 1963. He graduated his bachelor degree in National University Jakarta (1989), and finished his master and PhDdegree in Bogor Agricultural University focusing on plant biotechnology under the Faculty of Agriculture. He's currently working as a researcher in the Research and Development Center for Biotechnology and Genetic Resources, Ministry of Agriculture of the Republic of Indonesia. Some of his previous research are Application of Protoplast fusion technology in assembling new types of local citrus, Utilization of citrus rootstock to arbuscular mycorrhizal mutant to contro Phytophthora stem rot disease, and Testing somaclonal strain of soya bean through invitro selection for drought stress tolerant plant 